\title{
Paradigma Yuridis Kemanfaatan dan Kepatutan suatu Produk Hukum yang Mengalami Kebatalan Mutlak
}

\author{
Anajeng Esri Edhi Mahanani \\ Fakultas Hukum, Universitas Pembangunan Nasional "Veteran" Jawa Timur \\ J1. Rungkut Madya No. 1, Gununganyar, Surabaya \\ Anajengmahanani.ih@upnjatim.ac.id
}

\begin{abstract}
Abstrak
Produk hukum dibentuk untuk menjawab suatu permasalahan hukum di masyarakat. Dalam pembentukan produk hukum, harus dilihat syarat materiil dan formil sebagai dasar penyusunannya. Atas tidak terpenuhinya syarat-syarat tersebut, kemungkinan adanya klausul dinyatakan bahwa produk hukum tersebut batal, menjadi sangat kuat. Salah satu dampak tidak terpenuhinya syarat materiil suatu produk hukum adalah adanya upaya pembatalan mutlak. Tulisan ini akan mengkaji sisi kemanfaatan dan kepatutan suatu produk hukum yang mengalami kebatalan mutlak. Penelitian ini mengambil simpulan bahwa terdapat sisi positif dan negatif yang dapat dilihat berdasar teori utilitarianisme dan equity dari pembatalan mutlak suatu produk hukum.
\end{abstract}

Kata kunci: Produk Hukum, Kemanfaatan, Kepatutan, Batal Mutlak

\begin{abstract}
Legal products are formed to answer a legal problem in society. In the formation of legal products, the material and formal requirements must be seen as the basis for their preparation. Due to the nonfulfillment of these conditions, the possibility of a clause stating that the legal product is void is very strong. One of the effects of not fulfilling the material requirements of a legal product is an attempt at absolute cancellation. This paper will examine the usefulness and appropriateness of a legal product that is subject to absolute annulment. This research concludes that there are positive and negative sides that can be seen based on the theory of utilitarianism and the equity of the absolute cancellation of a legal product.
\end{abstract}

Keywords: Legal Product, Utility, Eqyity, Absolute nietig

\section{A. Pendahuluan}

Produk Hukum pada pokoknya merupakan produk dari pengambilan suatu kebijakan aparat berwenang yang juga merupakan cerminan arah kebijakan hukum, serta hasil dari suatu dari politik hukum, sebagaimana politik hukum oleh Prof. Muchsan ${ }^{1}$ diartikan sebagai ilmu bagian dari hukum yang membahas perbuatan aparat yang berwenang dalam memilih alternatif yang sudah tersedia untuk menciptakan suatu produk hukum guna mewujudkan tujuan negara, sangat memiliki peranan untuk menentukan arah bagaimana aparat yang berwenang dalam membentuk suatu produk hukum.

Suatu produk hukum seharusnya tidak melewatkan syarat-syarat pembentukannya yang menyebabkan produk hukum tersebut memiliki keabsahan yang kuat. Hal ini

\footnotetext{
${ }^{1}$ Muchsan, SistemPengawasan terhadap Perbuatan Aparat Pemerintah dan Peradilan Tata Usaha Negara di Indonesia, Liberty, Yogkyakarta, 2000, hlm. 14-15
} 
merupakan wujud dari jaminan suatu produk hukum harus memiliki legitimasi yuridis yang kuat sehingga dapat diterima masyarakat sebagai produk hukum yang tidak cacat.

Pertimbangan urgensi suatu produk hukum harus memiliki legalitas kuat, ditujukan guna memastikan legalitas pengambilan kebijakan atau perbuatan aparat dalm hal hubungan negara dengan warga negaranya. Pembentukan produk hukum tidak hanya melegalkan political will pemerintah pada saat itu, kemudian mengatur hak dan kewajiban masyarakat, namun juga memberi batasan dalam pelaksanaan kebijakan pemerintah sehingga tidak diselewengkan, namun ditujukan sebesar-besarnya guna kepentingan bangsa.

Pengawalan terhadap keberlakuan suatu produk hukum perlu untuk dijadikan fokus perhatian. Produk hukum yang sesuai dengan kebutuhan masyarakat sudah semestinya dapat dipertahankan dan dioptimalkan keberlakuannya. Sebaliknya, produk hukum yang tidak sesuai dengan kebutuhan dan dinamika masyarakat, dapat diteliti untuk kajian lebih mendalam.

Salah satu hal yang penting untuk diperhatikan adalah dalam hal syarat pembentukanya. Suatu produk hukum harus dibentuk dengan memenuhi syarat materiil serta formil pembentukannya. Sehingga pembentukan produk hukum dapat dikatakan sah dan memiliki legitimasi keberlakuan. Sebaliknya, terhadap produk hukum yang bermasalah, dalam hal ini tidak memenuhi syarat materiil, formil, maka perlu dikaji konsep kebatalan produk hukum tersebut.

Pemahaman akan konsep kebatalan produk hukum ini sangat penting, dikarenakan atas kebatalan satu produuk hukum dengan yang lain berdasarkan alasan dikaji dari syaratsyarat pembentukan produk hukum, dapat menimbulkan akibat hukum yang berbeda-beda. Artikel ini akan membahas tentang paradigma normatif produk hukum yang mengalami kebatalan mutlak (absolute nietig) dengan melihat dampak positif negatif.

\section{B. Telaah Konsep}

Syarat-sayarat suatu peraturan atau keputusan dianggap sah dan memiliki justifikasi adalah ketika setiap peraturan atau keputusan memenuhi syarat materiil serta formil. Syarat formil dan syarat materiil ini sagat terikat dalam hal penentuan legitimasi suatu produk hukum. Produk hukum dalam hal ini khususnya suatu keputusa tata negara memiliki syarat materiil dan formil yang harus dipenuhi, yakni sebagai berikut: ${ }^{2}$

1. Syarat materiil:

\footnotetext{
${ }^{2}$ W. Riawan Tjandra, Hukum Administrasi Negara, Universitas Atma Jaya Yogyakarta, 2008, hlm. 72.
} 
Anajeng Esri Edhi Mahanani: Paradigma Yuridis Kemanfaatan dan Kepatutan suatu Produk...

a. Produk hukum tersebut harus dibuat oleh aparat berwenang,

b. Dalam pembuatan/penyusunannya tidak mengalami kekurangan yuridis,

c. Keputusan Tata Usaha Negara harus berdasarkan suatu keadaan tertentu

d. Tujuan produk hukum yang dibuat sesuai dengan tujuan peraturan dasarnya.

2. Syarat formil:

a. Syarat-syarat yang ditentukan berkaitan dengan persiapan dan cara pembuatan suatu Keputusan Tata Usaha Negara.

b. Keputusan Tata Usaha Negara harus diberi bentuk yang ditentukan.

c. Syarat-syarat yang ditentukan berkaitan dengan pelaksanaan Keputusan Tata Usaha Negara.

d. Jangka waktu yang ditentukan antara timbulnya hal-hal yang menyebabkan dibuatnya suatu Keputusan Tata Usaha Negara dan pengumuman Keputusan Tata Usaha Negara itu tidak boleh dilewati.

Dari kedua kelompok syarat suatu produk hukum supaya dinyatakan sah (syarat materiil dan syarat formil), peletakan bobot persyaratan lebih kuat atau berat dalam hal keharusan untuk memenuhi syarat materiil. Maksudnya di sini adalah, meskipun kedua nya harus dipenuhi (syarat materiil dan formil) namun apabila salah satu dari ketiga syarat materiil di atas tidak terpenuhi maka putusan tersebut memiliki ancaman besar terhadap keabsahannya.

Terhadap produk hukum, khususnya Keputusan Tata Negara yang tidak sesuai atau tidak memenuhi syarat baik syarat materiil maupun formil, akan mendapati akibat hukum. Akibat hukum dari suatu produk hukum dinyatakan tidak memenuhi salah satu atau bahkan keseluruhan syarat materiil memiliki kategori sendiri-sendiri berdasarkan putusan kebatalan, yakni sebagai berikut: ${ }^{3}$

a.Absolute nietig (batal mutlak) diartikan suatu produk hukum tersebut dinyatakan batal mutlak (absolute nietig), sehingga menimbulkan suatu akibat hukum yang menyatakan bahwa suatu peristiwa yang ada dalam produk hukum maupun yang diakibatkan oleh produk hukum sejak keberlakuannya dianggap belum pernah ada, sehingga harus dikembalikan dalam keadaan semula.

b. Nietig van rechts wege (batal demi hukum) diartikan suatu produk hukum tersebut dinyatakan batal demi hukum, sehingga sebagian atau semua perbuatan/peristiwa dianggap tidak ada (dihapuskan) tanpa diperlukan suatu keputusan hakim atau keputusan suatu badan pemerintahan lain yang berkompeten untuk menyatakan batalnya sebagian atau seluruh akibat itu.

${ }^{3}$ Utrecht.1986.Pengantar Hukum Administrasi Negara.Surabaya: Pustaka Tinta Mas. Hlm.109-111. 
c. Vernetigbaar (dapat dibatalkan) diartikan suatu produk hukum tersebut dinyatakan dapat dibatalkan, sehingga bagi hukum suatu perbuatan/peristiwa yang dilakukan dan akibatnya dianggap ada sampai waktu pembatalan oleh hakim atau oleh suatu badan pemerintahan lain yang berkompeten (pembatalan itu diadakan karena pembuatan tersebut mengandung sesuatu kekurangan). Bagi hukum, perbuatan tersebut ada sampai waktu pembatalannya dan oleh sebab itu segala akibat yang ditimbulkan antara waktu mengadakannya sampai waktu pembatalannya, menjadi sah (terkecuali dalam hal undang-undang menyebut beberapa bagian akibat itu tidak sah). Setelah pembatalan maka perbuatan itu tidak ada dan -bila mungkin- diusahakan suapaya akibat yang telah terjadi itu semuanya atau sebagiannya hapus.

\section{Metode Penelitian}

Penelitian dalam artikel ini menggunakan jenis penelitian yuridis normatif. Jenis penelitian yuridis normatif digunakan karena dalam penelitian ini mengutamakan penggunaan data sekunder. Penelitian ini lebih mengutamakan data yang diperoleh tidak secara langsung dari narasumber.

Menurut Sunaryati Hartono, metode penelitian hukum normatif memiliki beberapa kegunaan di antaranya adalah mengetahui atau mengenal apakah dan bagaimanakah hukum positifnya mengenai suatu permasalahan tertentu, serta juga untuk mencari asas hukum, teori hukum, dan sistem hukum. ${ }^{4}$

Penelitian hukum yang merupakan penelitian hukum normatif ini menggunakan jenis data sekunder, yang mendorong Penulis untuk melakukan aktivitas pengumpulan data berupa studi pustaka dengan menggunakan teknik studi documenter. Data-data kemudian dikumpulkan untuk analisis bahan kajian dalam pembahasan.

Analisis data adalah proses pengorganisasian dan pengurutan data dalam pola, kategori, dan uraian dasar, sehingga akan dapat ditemukan tema dan dapat dirumuskan hipotesis kerja seperti yang disarankan oleh data. ${ }^{5}$ Analisis data juga diartikan sebagai proses penyederhanaan data ke dalam bentuk yang lebih mudah dibaca dan diinterpretasikan.

\footnotetext{
4 Sunaryati Hartono, 2006, Penelitian Hukum di Indonesia Pada Akhir Abad Ke-20, Edisi Pertama, Alumni, Bandung, hlm. 140-141.

${ }^{5}$ Lexi J Moleong, 2002, Metodologi Penelitian Kualitatif. Cet. kedua, PT Remaja Rosdakarya, Bandung, hlm. 143
} 
Interpretasi data dimaksudkan untuk mencari makna dan simplikasi yang lebih luas dari hasil-hasil penelitian. ${ }^{6}$

Data yang diperoleh dalam penelitian ini akan dianalisis secara kualitatif deskriptif, mengingat bahwa kajian ini lebih kepada kajian legal. Analisis secara kualitatif dilaksanakan dengan cara mengumpulkan data, kemudian data direduksi sampai dengan tahapan analisis.

\section{Pembahasan}

Tinjauan Kemanfaatan dan Kepatutan Suatu Produk Hukum yang Mengalami Kebatalan Mutlak

\section{a. Tinjauan Konsekuensi Suatu Produk Hukum Batal Mutlak}

Menurut teoritis, produk hukum yang dapat dihasilkan meliputi:

1) Regeling (peraturan), merupakan hasil dari kegiatan pengaturan. yang diartikan sebagai produk hukum tertulis dibawah undang-undang, diproduksi atau dibuat oleh pejabat tata usaha Negara yang fungsinya mempunyai daya ikat atau materinya sebagaian atau seluruh wilayah teritorial tersebut. Peraturan ini merupakan hasil dari kegiatan pengaturan.

2) Beschikking (keputusan), yang diartikan sebagai penetapan tertulis yang diproduksi oleh pejabat tata usaha negara dan mendasarkan diri terhadap peraturan perundang-undangan tertentu, bersifat konkrit, individual dan final. Keputusan yang dimaksud merupakan hasil kegiatan penetapan atau pengambilan keputusan administratif.

3) Vonnis (putusan hakim) yang dihasilkan melalui penghakiman atau pengadilan. (Dalam hal ini vonnis juga dimaksudkan masuk dalam keputusan atau beschik.king).

Produk hukum tersebut di atas dapat kemudian dipertanyakan keabsahannya apabila tidak memenuhi persyaratan dalam hal pembentukan suatu produk hukum. Peraturan (regeling) misalnya, yang mana dibentuk oleh lembaga negara yang berwenang membentuk peraturan perundang-undangan atas dasar atribusi kekuasaan dalam UUD 1945 yakni sebagi berikut: MPR dalam menetapkan Undang-Undang Dasar (Pasal 3), Presiden dan DPR dalam membentuk Undang-undang (Pasal 5 ayat (1) jo. Pasal 20 ayat (1) s/d ayat (5)), Presiden dalam membentuk Peraturan Pemerintah dan Peraturan Pemerintah sebagai Pengganti Undang-Undang (Pasal 5 ayat (2) dan Pasal 22); Pemerintahan Daerah dalam membentuk Peraturan Daerah (Pasal 18 ayat (6). Selain peraturan perundang-undangan di atas, Pasal 7 ayat (1) Undang - Undang Nomor 12 Tahun 2011 tentang Pembentukan

\footnotetext{
${ }^{6}$ Maria SW.Sumardjono, 2014, Bahan Kuliah: Metodologi Penelitian Ilmu Hukum, Universitas Gadjah Mada, Yogyakarta, hlm. 32.

${ }^{7}$ Jimly Asshidiqie. Peribal Undang-Undang. Rajawali Pers, Jakarta, 2010, hlm.8
} 
Peraturan Perundang-undangan (“UU No. 12 Tahun 2011”), juga menambahkan 2 peraturan perundang-undangan atas dasar kewenangan atribusian, yakni Ketetapan MPR serta Peraturan Presiden. Serta lembaga-lembaga negara lain yang diatur oleh UndangUndang Dasar maupun Undang-Undang. Untuk peraturan (regeling) kebatalan ditentukan oleh Mahkamah Konstitusi dalam pengujian Undang-Undang terhadap Undang-Undang Dasar, serta Mahkamah Agung dalam pengujian Peraturan Perundang-Undangan di bawah Undang-Undang. Kebatalan mutlak terhadap suatu produk peraturan (regeling) tentunya menghapus ketentuan yang digugat untuk ditinjau ulang atau keseluruhan ketentuan dalam peraturan yang mengakibatkan peraturan (regeling) tidak dapat diberlakukan kembali. Namun perlu diperhatikan kebatalan dalam suatu peraturan ini tidak berlaku surut.

Selanjutnya adalah pembatalan produk hukum keputusan. Produk hukum ini mengarah pada produk hukum yang dibentuk oleh pejabat Tata Usaha Negara, serta putusan (vonnis) yang dibentuk hakim dalam proses di pengadilan. Keputusan/ketetapan yang merupakan vonnis hakim di pengadilan, merupakan produk hukum yang didasarkan pada kewenangan yang diberikan oleh undang-undang terhadap lembaga yudikatif. Sedangkan, keputusan khususnya keputusan yang dibentuk pejabat TUN, merupakan hasil dari delegasi kewenangan (delegatie van bevoegdheid), yang bersifat delegated legislator yang disebabkan adanya delegasi kewenangan dari pemerintahan kepada badan atau jabatan tata usaha negara tertentu.

Keputusan/ketetapan tersebut dapat dibatalkan karena memiliki kekurangankekurangan dalam hal pemenuhan syarat keabsahan pembentukan suatu produk hukum. Donner ${ }^{8}$ mengemukakan bahwa kekurangan dalam ketetapan dapat mengakibatkan:

a. Ketetapan itu harus dianggap batal sama sekali;

b. Berlakunya ketetapan itu dapat digugat;

- Dalam bandingan (beroep)

- Dalam pembatalan oleh jabatan (amtshalve vernietiging) karena bertentangan dengan undang-undang

- Dalam penarikan kembali (intrekking) oleh kekuasaan yang berhak (competent) mengeluarkan ketetapan tersebut.

c. Dalam hal ketetapan tersebut, sebelum dapat berlaku, memerlukan persetujuan (peneguhan) suatu badan kenegaraan yang lebih tinggi, maka persetujuan itu tidak diberi;

d. Ketetapan itu diberi suatu tujuan lain dari pada tujuan permulaannya (konversie, conversie).

${ }^{8}$ Dikutip dari Utrecht.1986.Pengantar Hukum Administrasi Negara.Surabaya: Pustaka Tinta Mas. Hlm.114. 
Ada juga kemungkinan bahwa kekurangan tersebut sama sekali tidak mempengaruhi berlakunya ketetapan. Di samping kemungkinan ini masih ada lagi kemungkinan recovalescentie. Karena suatu tambahan atau suatu peneguhan kemudian, maka ketetapan masih juga berlaku.

Lalu bagaimana apabila suatu keputusan atau ketetapan dinyatakan batal mutlak? Van der $\mathrm{Wel}^{9}$ memberikan pendapat, bahwa suatu ketetapan yang menetapkan sesuatu yang sungguh-sungguh tidak mungkin dilaksanakan dapat dianggap batal sama sekali. Mengenai ketetapan-ketetapan lain, kita harus melihat apakah kekurangan-kekurangan yang bersangkutan adalah kekurangan "essentieel" arau kekurangan bukan "essentieel". Kekurangan bukan "essentieel" tidak dapat mempengaruhi berlakunya ketetapan. Mengenai kekurangan "essentieel" harus dilihat beratnya kekurangan. Apabila kekurangan begitu berat sehingga ketetapan yang bersangkutan sebetulnya tidak berupa ketetapan yang sah, maka ketetapan yang bersangkutan itu dapat dianggap batal sama sekali (batal mutlak). Apabila kekurangan tidak begitu berat, maka ketetapan yang bersangkutan dapat dianggap batal terhadap subjek hukum yang tidak mempunyai alat untuk menggugat berlakunya ketetapan itu.

Van der Pot mengungkapkan bahwa suatu ketetapan atau keputusan dianggap sah apabila: ${ }^{10}$

1) Keputusan harus dibuat oleh alat (organ) yang berwenang membuatnya.

2) Oleh karena keputusan itu adalah suatu pernyataan kehendak, maka pembentukan kehendak itu tidak boleh mengandung kekurangan yuridis, yaitu tidak boleh mengandung paksaan, kekeliruan dan penipuan.

3) Keputusan itu harus diberi bentuk yang ditetapkan dalam peraturan yang menjadi dasarnya, dan pembuatannya harus juga memperhatikan tata cara membuat keputusan bilamana tata cara ini ditetapkan dengan tegas dalam peraturan dasar tersebut.

4) Isi dan tujuan harus sesuai dengan isi dan tujuan peraturan dasarnya.

Hal-hal tersebut di atas dengan dicocokan syarat materiil suatu produk hukum, apabila tidak dipenuhi dapat menyebabkan suatu ketetapan/keputusan batak mutlak. Bentuk keputusan tersebut dapat dikatakan batal mutlak, apabila tuntutan pembatalan suatu perbuatan dapat dilakukan oleh setiap orang. Putusan pembatalan yang berbunyi batal mutlak ini memiliki konsekuensi yuridis suatu peristiwa yang ada dalam produk hukum maupun yang diakibatkan oleh produk hukum sejak keberlakuannya dianggap belum

${ }^{9}$ Ibid.Hlm.116.

${ }^{10}$ DalamEny Kusdarini.2011.Dasar-Dasar HukumAdministrasi Negara.Yogyakarta:UNY Press.Hlm.123-124 
pernah ada, sehingga harus dikembalikan dalam keadaan semula. Hal ini tentunya akan membawa dampak serius terhadap peristiwa-peristiwa hukum yang terjadi setelah keputusan/ketetapan dibentuk kemudian dinyatakan batal mutlak. Tidak diakuinya keberadaan suatu peristiwa hukum dan tuntutan dikembalikannya keadaan seperti keadaan semula akan sangat sulit ketika keadaan atau peristiwa hukum yang dimaksud akan memberikan kerugian yang lebih buruk apabila dikembalikan pada kondisi semula.

Maka kemudian terdapat ketentuan, bahwa belum tentu keputusan/ketetapan yang dibuat dengan tidak mengindahkan kategori-kategori tersebut menjadi tidak sah. Sah tidaknya suatu keputusan tadi masih tergantung pada besarnya obyek yang diatur dalam keputusan. Sehingga akhirnya yang dapat menilai sah tidaknya suatu keputusan adalah pejabat TUN yang lebih tinggi atau Peradilan Tata Usaha Negara, itupun harus dilihat secara kasuistik. ${ }^{11}$ Akan tetapi, juga terdapat ajaran yang menganalisa, apabila Pejabat TUN yang mengeluarkan keputusan di dalam menduduki jabatannya ternyata tidak legal (sah), maka dapat diselesaikan dengan ajaran functionare defait, yaitu doktrin/ajaran yang menyatakan bahwa dalam keadaan memaksa/istimewa/darurat Pejabat TUN tidak legal atau pengangkatannya mengandung kekurangan, sebatas masyarakat umum menerimanya sebagai Pejabat TUN yang legal, maka perbuatan-perbuatan yang dilakukannya atau keputusan yang dikeluarkannya adalah sah. Akan tetapi apabila masyarakat tidak menerimanya maka keputusan yang dikeluarkannya tidak sah. ${ }^{12}$

Dengan ada keputusan/ketetapan sah dan ada keputusan/ketetapan yang tidak sah. Suatu keputusan/ketetapan dianggap tidak sah apabila keputusan tadi mengandung kekurangan yang esensial, salah satunya dibentuk oleh pejabat TUN yang tidak berwenang, tidak jelas kewenangannya serta tidak diterima masyarakat melihat adanya ajaran functionare defait, sehingga tidak dapat diterima menjadi bagian dari ketertiban hukum. Kesimpulannya, berdasarkan teori functionare de faite, suatu Keputusan Tata Usaha Negara tetap dianggap berlaku walaupun tidak memenuhi syarat diatas (formil dan materiil), apabila memenuhi 2 (dua) syarat yang bersifat kumulatif, yaitu:

a. Tidak absahnya keputusan itu karena kabur, terutama bagi penerima keputusan.

b. Akibat dari keputusan itu berguna bagi kepentingan masyarakat.

Teori kebatalan "batal mutlak" apabila tidak memenuhi syarat-syarat materiil dan esensial sebagaimana yang dikemukakan Van der Wel sebelumnya, juga ditentang oleh

${ }^{11}$ Ibid.

${ }^{12}$ Ibid.Hlm.37 
Anajeng Esri Edhi Mahanani: Paradigma Yuridis Kemanfaatan dan Kepatutan suatu Produk...

Stellinga ${ }^{13}$, Stellinga juga mengukur kekurangan "essentieel" dengan kasuistis. Hal ini dikarenakan pengukuran kekurangan ini "essentieel" atau tidak menjadi kabur. Apalagi yang berhubungan dengan hal keputusan administrasi negara, "doelmatigheid" yakni kemanfaatan menjadi suatu persoalan yang lebih diperhatikan daripada rechtmatigheid itu sendiri.

Berangkat dari pendapat Stellinga serta melihat dampak dari akibat hukum produk hukum dinyatakan batal mutlak tesebut, penulis kemudian akan mengkaji dampak positif negatif dari teori kebatalan mutlak terhadap suatu produk hukum tersebut dalam kajian selanjutnya.

\section{a. Dampak Positif-Negatif Suatu Produk Hukum yang Mengalami Kebatalan Mutlak}

Suatu produk hukum yang dinyatakan batal mutlak dengan alasan tidak memenuhi syarat materiil, akan berdampak baik terhadap produk hukum yang kemudian dianggap tidak ada maupun peristiwa hukum yang harus dikembalikan kepada keadaan semula. Penulis sebelumnya telah menilai, apabila "rehabilitasi" keadaan untuk dikembalikan pada keadaan semula bersifat kasuistis yang terkadang sulit untuk dilakukan.

Contoh tentang penetapan perkawinan yang digugat oleh ayah mempelai wanita (istri dari A) yang menikah tanpa disaksikan oleh sang ayah (C). A dan B (istriA) menikah dengan dikaruniai 3 orang anak dengan sudah ditetapkan terhadap ketiganya akta lahir yang mencantumkan A dan B sebagai orangtua dari tiga anak tersebut. C menuntut pembatalan perkawinan dengan alasan dasar perkawinan tersebut tidak menghadirkannya sebagai saksi wali tapi justru menunjuk saksi hakim. Pengadilan pada saat itu kemudian memutuskan bahwa penetapan perkawinan yang semula sah dengan bukti pencatatan di Kantor Catatan Sipil batal mutlak, sehingga dampaknya tidak hanya perkawinan dianggap tidak pernah ada namun juga keberadaan anak-anak dari A dan B menjadi anak diluar nikah, sehingga penetapan akta dari Kantor Catatan Sipil juga tidak pernah dianggap ada, semua batal.

Dari contoh putusan batal mutlak terhadap keputusan/ketetapan yang sudah ada tersebut, memang didasarkan pada alasan tidak dipenuhinya syarat materiil yang menunjukkan penetapan sahnya perkawinan tersebut mengalami kekurangan yuridis. Akan tetapi melihat dampak daripada putusan batal mutlak, justru menurut penulis banyak menimbulkan kerugian yang besar bagi A dan B tentunya, serta yang paling merugi justru status keberadaan ketiga anak hasil perkawinan A dan B.

\footnotetext{
${ }^{13}$ Ibid.Hlm.117.
} 
Melihat contoh tersebut di atas, penulis ingin meninjau teori kebatalan mutlak ini dilihat dari sisi positif dan negatif secara lebih lanjut. Dari pendapat Stellinga misalnya, yang mengemukakan bahwasannya doelmatigheid merupakan tujuan yang paling utama dari suatu produk hukum, dibandingkan dengan rechtmatigheid, ini menunjukkan bahwa Stellinga lebih mengedepankan pertimbangan kemanfaatan dalam mengkaji keberadaan produk hukum yang memiliki kekurangan esensial, dibanding dengan kepastian secara rechtmatigheid untuk kemudian langsung memutuskan keputusan/ketetapan sebagai produk hukum tersebut batal mutlak.

Hal ini juga sejalan dengan teori Utilitarianisme oleh Jeremy Bentham yang diperkuat oleh John Stuart Mill. Teori ini juga mempertimbangkan kemanfaatan dibanding dengan kepastian hukum dalam pandangan rechtmatigheid. Utilitarianisme berasal dari bahasa latin "utilis" yang berarti useful, bermanfaat, berfedah dan mengguntungkan. Menurut utilitarianisme,hukum yang baik adalah hukum yang dapat memenuhi prinsip memaksimalkan kebahagiaan dan meminimalkan rasa sakit dalam masyarakat. ${ }^{14}$

Menurut pemikiran utilitarian, bahwa perlu juga standar moralitas di mana dapat menegaskan aturan-aturan untuk memimpin manusia. Hasil pokok dari utilitarianisme sebagai sebuah teori moral adalah untuk membedakan suatu tindakan yang benar dan yang salah dari kebaikan atau keburukan dari pribadi yang melakukan suatu perbuatan. Seorang dapat menjadi baik secara moral dalam pandangan bahwa ia dapat selalu bertindak dari maksud yang baik. ${ }^{15}$

Kesimpulan yang dapat diambil, bahwasannya kemanfaatan tidak diukur secara kuantitatif melainkan secara kualitatif. Begitu pula atas kemanfaatan putusan penyataan yang memuat teori kebatalan terhadap suatu produk hukum yang berimbas pada peristiwa serta keadaan hukum lain. Melihat cotoh kasus sebelumnya yang telah dibahas, kemanfaatan perlu dipertimbangkan guna menentukan apakah kebatalan mutlak yang menuntut rehabilitasi ke keadaan semula pas untuk diterapkan dalam keputusan/ketetapan yang memang tidak memenuhi syarat materiil. Hal ini tentunya dengan mempertimbangkan apakah keputusan tersebut bermanfaat bagi pihak yang lebih banyak secara kualitas tidak hanya "kuantitas" hitung-hitungan ketentuan pasal seperti apa. Penafsiran hakim yang hanya melihat dari bunyi pasal untuk memutuskan dalam suatu pengadilan, tidak seharusnya hanya ditafsirkan secara bahasa tanpa memperhatikan sisi kemanfaatan. Melihat

${ }^{14}$ Antonius Cahyadi dan E.Fernando M.Pengantar ke Filsafat Hukum.Jakarta:Kencana.Hlm.62.

${ }^{15}$ Richard H. Popkin dan Avrum Stroll.1969.Philosophy Made Simple.London: W. H. Allen \& Company Ltd.Hlm. 3 
hal ini suatu putusan batal mutlak tentunya justru berdampak negatif apabila melihat kasusistik tersebut.

Dampak positif dan negatif ini kemudian penulis tinjau melalui teori tujuan hukum yang dikemukakan oleh Gustav Radburch, di mana hukum dibuat pasti memiliki cita atau tujuan, tujuan utama dari hukum menurutnya ialah kepastian hukum, keadilan dan kemanfaatan. ${ }^{16}$ Melihat ketentuan syarat-syarat keabsahan suatu produk hukum yang digunakan dasar untuk memutuskan produk hukum batal mutlak memang menunjukkan dampak positif daripada putusan batal mutlak. Teori kebatalan mutlak terhadap produk hukum yang tidak memenuhi syarat materiil sebagai syarat yang esensial memberikan suatu bentuk kepastian, supaya nantinya dalam mengatur, menetapkan, memutuskan suatu produk hukum benar-benar memperhatikan syarat-syarat keabsahan suatu produk hukum, utamanya syarat materiil yang memiliki bobot kekuatan yang besar. Penulis hanya melihat

\section{dampak positif kebatalan mutlak sebatas kepastian hukum.}

Lain halnya dari sisi keadilan dan kemanfaatan yang menjadi tujuan hukum lainnya. Keadilan dilengkapi oleh equity (kepatutan) diperlukan dalam keberlakuannya. Equity dapat didefenisikan sebagai kebajikan yang mendorong manusia untuk menggunakan apa yang menjadi haknya untuk berbuat secara rasional menurut akal sehatnya.$^{17}$ Equity dalam pelaksanaannya tidak berlawanan dengan hukum, bahkan pengaruhnya semakin kuat dalam penyelesaian sengketa ketika aspek hukum tidak mengaturnya. ${ }^{18}$

Kelalaian dalam praktek, dapat merubah wujud keadilan yang seharusnya berwatak kebajikan (virtue), menjadi bentuk pengingkaran terhadap keadilan itu sendiri. Karakter keadilan adalah objektif, zakelijk dan umum, berarti keadilan yang demikian itu mutlak, memaksa dan dalam pelaksanaannya terlalu abstrak, sehingga tidak mempertimbangkan situasi keadaan person-person serta terlalu menyamaratakan. Kualitas individu serta kondisi-kondisi tertentu seharusnya juga menjadi perhatian tanpa mereduksi keadilan itu sendiri, justru menyempurnakan keberlakuannya. Karena itu, keadilan dalam prakteknya dikoreksi dan disandingkan dengan equity (kepatutan). Equity sangat mempertimbangkan aspek-aspek penting yang melingkupi suatu kasus, yaitu itikad baik, maksud para pihak, situasi atau keadaan-keadaan, dan lain-lain. ${ }^{19}$ Dalam hal ini keadilan yang disandingkan dengan kepatutan sebagai suatu tujuan hukum perlu diperhatikan dalam menentukan teori

${ }^{16}$ Dalam Muhamad Erwin, Filsafat Hukum Refleksi Kritis terbadap Hukum. Rajawali Pers, Jakarta, 2013.

${ }^{17}$ L.B. Curzon..Equity, MacDonald \& Evans, London, 1967, hlm 4.

${ }^{18}$ Ibid.,hal. 27.

${ }^{19}$ O. Notohamidjojo, .Masalah Keadilan, Tirta Amerta, Semarang, 1971, hlm. 13. 
kebatalan yang akan digunakan, apakah kebatalan mutlak, batal demi hukum ataukah dapat dibatalkan. Teori kebatalan mutlak apabila dilihat dari tujuan keadilan yang disandingkan dengan kepatutan ini justru memperlihatkan dampak negatif suatu putusan batal mutlak, yang tidak memperhatikan unsur keadilan dalam memutuskan kebatalannya.

Apalagi ketika lagi-lagi berbicara tentang kemanfaatan yang sebelumnya telah disinggung berdasarkan ajaran Jeremy Bentham dan John Stuart Mill, memperlihatkan dampak negatif daripada putusan batal mutlak terhadap suatu produk hukum, ketika putusan tersebut justru harus mengembalikan kepada keadaan semula yang justru berdampak merugikan para pihak. Hal ini sebenarnya kasuistis sebagaimana telah dibahas sebelumnya tentang faktor esensial.

Penting kemudian bagi hakim dalam memutuskan suatu produk hukum tidak hanya mengartikan secara leksikal bunyi ketentuan yang memutuskan keberadaan keabsahan suatu produk hukum, namun juga sisi keadilan serta kemanfataan yang dapat diambil. Teori kebatalan dapat diambil berdasarkan teori batal demi hukum ataupun dapat dibatalkan (untuk perkara/kasus yang paling ringan), sehingga dampak yuridisnya tidak terlalu berdampak serius terhadap peristiwa/keadaan hukum yang ada sebelum produk hukum tersebut dibatalkan.

\section{Penutup}

Putusan pembatalan yang berbunyi batal mutlak memiliki konsekuensi yuridis, bahwa suatu peristiwa yang ada dalam produk hukum maupun yang diakibatkan oleh produk hukum sejak keberlakuannya dianggap belum pernah ada, sehingga harus dikembalikan dalam keadaan semula. Berbicara tentang kebatalan mutlak pada suatu produk hukum, maka dapat dianalisa kebatalan mutlak pada produk hukum peraturan, maupun keputusan.

Kebatalan mutlak terhadap suatu produk peraturan (regeling) merupakan putusan dari gugatan penghapusan ketentuan untuk ditinjau ulang, sehingga keseluruhan ketentuan dalam peraturan yang mengakibatkan peraturan (regeling) tidak dapat diberlakukan kembali. Untuk pembatalan produk hukum keputusan, yang mana mengarah pada produk hukum yang dibentuk oleh pejabat Tata Usaha Negara, serta putusan (vonnis) yang dibentuk hakim dalam proses di pengadilan, dapat dibatalkan karena memiliki kekurangan-kekurangan dalam hal pemenuhan syarat materiil keabsahan pembentukan suatu produk hukum. Pembatalan mutlak produk hukum baik peraturan maupun keputusan, dapat dilaksanakan apabila tuntutan pembatalan suatu perbuatan dapat dilakukan oleh setiap orang. Hal ini 
tentunya akan membawa dampak serius baik terhadap produk hukum yang kemudian dianggap tidak ada maupun peristiwa hukum yang harus dikembalikan kepada keadaan semula.

Pembahasan berlanjut pada tinjauan yuridis dampak positif negatif suatu produk hukum dinyatakan mengalami kebatalan mutlak (absolute nietig). Hal ini kemudian ditinjau melalui teori utilitarianisme sekaligus teori tujuan hukum, yakni kepastian hukum, keadilan dan kemanfaatan.

Melihat ketentuan syarat-syarat keabsahan suatu produk hukum yang digunakan dasar untuk memutuskan produk hukum batal mutlak memang menunjukkan dampak positif daripada putusan batal mutlak. Teori kebatalan mutlak terhadap produk hukum yang tidak memenuhi syarat materiil sebagai syarat yang esensial memberikan suatu bentuk kepastian hukum, supaya nantinya dalam mengatur, menetapkan, memutuskan suatu produk hukum benar-benar memperhatikan syarat-syarat keabsahan suatu produk hukum, utamanya syarat materiil yang memiliki bobot kekuatan yang besar.

Selanjutnya dalam hal keadilan yang disandingkan dengan kepatutan sebagai suatu tujuan hukum perlu diperhatikan dalam menentukan teori kebatalan yang akan digunakan, apakah kebatalan mutlak, batal demi hukum ataukah dapat dibatalkan. Teori kebatalan mutlak apabila dilihat dari tujuan keadilan yang disandingkan dengan kepatutan ini justru memperlihatkan dampak negatif suatu putusan batal mutlak, yang tidak memperhatikan unsur keadilan dalam memutuskan kebatalannya.

Kemudian ditinjau pula dari tujuan hukum kemanfaatan, memperlihatkan dampak negatif daripada putusan batal mutlak terhadap suatu produk hukum, ketika putusan tersebut justru harus mengembalikan kepada keadaan semula yang justru berdampak merugikan para pihak. Hal ini sebenarnya kasuistis sebagaimana mempertimbangkan faktor esensial.

\section{DAFTAR PUSTAKA}

Antonius Cahyadi dan E.Fernando M. 2011. Pengantar ke Filsafat Hukum. Jakarta: Kencana. Eny Kusdarini.2011.Dasar-Dasar HukumAdministrasi Negara. Yogyakarta: UNY Press. Jimly Asshidiqie. 2010.Perihal Undang-Undang. Jakarta:RajawaliPers. L.B. Curzon.1967.Equity. London: MacDonald \& Evans. Muchsan, 2000, Sistem Pengawasan terhadap Perbuatan Aparat Pemerintah dan Peradilan Tata Usaha Negara di Indonesia. Yogyakarta: Liberty.

Muhamad Erwin. 2013. Filsafat Hukum Refleksi Kritis terhadap Hukum. Jakarta: Rajawali Pers. O. Notohamidjojo. 1971. Masalah Keadilan, Semarang: TirtaAmerta. 
Richard H. PopkindanAvrum Stroll. 1969. Philosophy Made Simple.London: W. H. Allen \& Company Ltd.

Utrecht. 1986. Pengantar Hukum Administrasi Negara.Surabaya: Pustaka Tinta Mas.London: Longmans, Green, Reader, and Dyer, 1871).

W. Riawan Tjandra. 2008. Hukum Administrasi Negara. Yogyakarta : Universitas Atma Jaya. 